Title: Law and the Quest for Autonomy in the Western Tradition

Author(s): Martin Bernier

Source: St Andrews Law Journal, 1:1 (November 2020), 92-95

Published by: Institute of Legal and Constitutional Research, University of St Andrews

DOI: https://doi.org/10.15664/stalj.v1i1.2352

This work is protected under Creative Commons Attribution 4.0 International (CC BY 4.0) License 2021.

The Author(s) retain copyright holding, having permitted the St Andrews Law Journal to distribute (publish) their work. All written content, Copyright @ the Author(s)

The St Andrews Law Journal is an Open Access publication of the University of St Andrews, published by the Institute of Legal and Constitutional Research with support from the University of St Andrews Journal Hosting Service

All use subject to:

https://creativecommons.org/licenses/by/4.0/

ISSN 2634-5102 


\section{Law and the Quest for Autonomy in the Western Tradition}

By Martin Bernier

\section{|Preamble|}

| This paper shall focus on the evolving features of autonomy and normativity in Western societies. The autonomy of Law as a product of deliberate will, regardless of other metaphysical or scientific considerations, is perpetually questioned in modern discussions of legality. |

Attempting to provide a legal definition of democracy, the Austrian jurist Hans Kelsen depicted it as a regime which aim is to avoid the "torment of heteronomy". Making sure that the law is made by - or in the name of - the people that abide by it, the democratic regime indeed avoids the imposition of an external law to a body politic. However, fostering autonomy has not always been the primary role attributed to law, nor its only purpose in history. It is therefore necessary to interrogate the relationship between law and autonomy in the Western tradition. The line of questioning here is twofold; it must address the issue of the autonomy of law itself and then its ability, as a normative tool, to render a society autonomous. The aim of this article is to trace the links between the roots of the "rule of law" ideal - instituting the autonomy of law - and the will to envision law as a product of wilful human deliberation, thus proclaiming autonomy.

One must begin by considering the Greek roots of the rule of law and the role of the Gregorian Reform in affirming the supremacy and the autonomy of law. Increasing emphasis is then placed on the impact of the French Revolution in redefining law as the product of human reason, distinct from any other normative source. Finally, this investigation aims at questioning the persistence of this ideal today against the potential emergence of new overarching principles, such as economics, threatening the autonomy of human reason and its role in the lawmaking process. The first step in enquiring about the conceptual links between law and autonomy is to explain how the autonomy of law theoretically precedes the use of legal science in an effort to foster autonomy. In short, the autonomy of law can be defined as the ability of a legislative system to define its own rules and to avoid being ruled by other laws. For instance, in a despotic regime, the law is not autonomous as it is 
subject to the will of the despot. The autonomy of law is therefore consubstantial to the idea of the rule of law. The rule of law means that all members of a society - including and especially the government - are subject to legal rules. This affirms the supremacy of law. Perhaps the most significant feature induced by this idea is that the lawmakers themselves are bound by the law. This guarantee is a prerequisite to ensure that law cannot be turned against the society by a governing minority and threaten its autonomy.

This idea of the autonomy of law has a long history in the Western tradition of legal thought. As Alain Supiot explains, we can trace back this ideal to Ancient Greece. In Plato's Laws for instance one can find the idea that the rulers must be the slaves and the servants of the laws. ${ }^{1}$ Later on, the supremacy of the law in the West was strengthened as a consequence of the Gregorian Reform. Indeed, the works of Harold Berman have shown how, in the twelfth century, the pope's will to turn the Church of Rome into a state and to spread the canon law in Christian states led to an affirmation of the supremacy of the law. It was the coexistence in the same political communities of different autonomous legal systems - secular and canon law - that made the supremacy of law in these communities possible. This led to the idea that, as Berman states, "the supreme political authority -the king, the pope himself- may make law (...) but he may not make it arbitrarily, and until he has remade it - lawfully- he is bound by it." ${ }^{2}$ This vision of the law is still remaining today in Western legal traditions where the autonomy of law and the necessity for the rulers to abide by it is no longer questioned.

If Ancient Greece teaches us, through the words of Plato, the importance of the rule of law, the democratic regime instituted in Athens was also the first to introduce the idea that a city is governed by the laws it has itself made, thus fostering autonomy. The linguistic shift from thesmos to nomos during the sixth and fifth centuries before Christ outlines this change from a law imposed to the citizens to a law made by them. ${ }^{3}$ This idea, as much as the idea of the rule of law, has crossed the centuries and was especially praised by the French

${ }^{1}$ Supiot, La gouvernance par les nombres, p. 81

2 Berman, Law and Revolution II, p. 5

3 Supiot, La gouvernance par les nombres, p. 84 
revolutionaries of the eighteenth century. Indeed, we can read in the Declaration of the Rights of Man and Citizen that "the law is the expression of the general will" (Article 6). It therefore follows from this principle the idea that law is the product of wilful human deliberation and that it must be adopted after a reasonable debate. 4 Law is clearly understood here as a normative tool that must enable the society to determine its own governing principles and rules, without referring to any transcendental principle. The French revolutionaries thus promoted both the autonomy of law, affirming that "any society in which the guarantee of rights is not assured, nor the separation of powers determined, has no Constitution" (Article 16 of the Declaration), and the use of law to render the society autonomous by determining rationally its ruling principles. The emphasis placed on reason in the quest for autonomy is especially important. In fact, a society can only be said to escape the "torment of heteronomy" when it refuses any external source of normativity. The French revolutionaries thus rejected the divine principles, turning rather to Deist rationalism, in order to truly found their laws in human reason. More specifically, the rationality praised by the revolutionaries and adopted by their successors was mostly rooted in individualism and utilitarianism. This was clearly visible in the Criminal Code enacted by Napoleon in 1810 for instance, where more emphasis was placed on deterring criminal acts by fear of penalties than on punishment. 5 This illustrates the will to regulate rationally the behaviours of the citizens rather than condemning acts for their intrinsic evilness or their noncompliance with moral standards dictated by religion.

After this historical overview of both the idea of the autonomy of law and its aim to foster autonomy in the societies it rules, it is necessary to study how these ideals survive today and to analyse which evolutions they went through. This paper shall focus on one aspect that has implied major changes in the way we conceive of the autonomy of law, namely the preeminent role taken by economics in the normative order. This evolution was first analysed by Karl Polanyi in The Great Transformation, where he explained the huge impact of

4 Herzog, A Short History of European Law, p. 187

5 Berman, Law and Revolution II, p. 12 
the disembedding of the economy on the British society between the eighteenth and nineteenth centuries. According to him, the economy used to be a sphere of social life among others, playing rather a minor role in it, but, following the development of capitalism, it began occupying a preeminent role in the organisation of the societies and even became overarching. The direct consequence of the growing importance of economics in law is that, instead of being seen as the product of wilful human deliberation, it is now argued by some that law should be determined in order to maximise individual utilities. ${ }^{6}$ This is the approach praised by the 'Law and Economics' doctrine of the School of Chicago.

According to the supporters of this economic analysis of law, all citizens must be understood as rational actors attempting to maximise their utility ${ }^{7}$ and the legal sanctions are seen as market prices. ${ }^{8}$ The interesting feature of this evolution is that it does not completely reject the earlier principles according to which law should be based on human reason but it understands human reason only as economic rationality. This emphasis on economic rationality necessarily threatens the autonomy of the society as its members, as workers and consumers, are seen as mere commodities and automatons trying to optimise their behaviours. Moreover, the question here is the direction that the society chooses to follow through the laws it enacts. The Greeks for instance aimed at reaching a just city whereas the goal of most economic analysts of the law is to maximise productivity and growth. The problem with someone not respecting a contract is therefore not of a moral nature but rather that "without enforceable contracts, people have difficulty cooperating with each other, so productivity is relatively low". 9 The autonomy of law and its potential to foster autonomous societies is thus a major feature of the Western legal tradition but it is not exempt from questionings and threats. The virtue of wilful human deliberation is indeed competing today with powerful calculators and the divine law rejected by the French revolution could be replaced by the invisible hand of market theorised by Adam Smith.

${ }^{6}$ Supiot, Homo juridicus, p. 26

${ }^{7}$ Shavell, Foundations of economic analysis of law, p. 1

${ }^{8}$ Cooter, 'Expressive Law and Economics', p. 585

9 Ibid., p.604 


\section{Bibliography}

Berman, Harold. Law and Revolution II: The Impact of the Protestant Reformations on the Western Legal Tradition. Harvard University Press, 2003.

Cooter, Robert. "Expressive Law and Economics." The Journal of Legal Studies 27, no. S2 (1998): 585-607.

Herzog, Tamar. A Short History of European Law: The Last Two and a Half Millennia. Harvard University Press, 2018.

Shavell, Steven. Foundations of Economic Analysis of Law. Harvard University Press, 2004.

Supiot, Alain. Homo juridicus: essai sur la fonction anthropologique du droit. Seuil, 2005.

Supiot, Alain. La gouvernance par les nombres. Fayard, 2015 